\title{
Ophthalmic findings in a group of ambulatory patients infected by human immunodeficiency virus (HIV): a prospective study
}

\author{
R C HUMPHRY,' J N WEBER,?' AND R J MARSH
}

From 'St George's Hospital, London SW17, 'St Mary's Hospital, London W2, and the 'Western Ophthalmic Hospital, London NWI

SUMMARY Twenty-eight patients with either the acquired immune deficiency syndrome (AIDS) or persistent generalised lymphadenopathy (PGL) were studied prospectively as outpatients for up to one year. Six patients had fundal cotton wool spots at some stage of their follow-up and all six suffered opportunistic infections associated with AIDS. We suggest that ocular abnormalities may be prognostic for opportunistic infection in AIDS and discuss the wide range of ophthalmic complications consequent to HIV infection.

The human immunodeficiency virus type III (HIV) is now implicated as the cause of the acquired immune deficiency syndrome (AIDS) and of related disorders, such as persistent generalised lymphadenopathy (PGL). ${ }^{1-5}$ A recent study of AIDS and AIDS risk patients by both membrane immunofluorescence and competitive radioimmunoassay showed that 97\% of AIDS patients were seropositive for antibodies to HIV, as were $89 \%$ of patients with PGL, $17 \%$ of symptomless homosexual men, $34 \%$ of haemophiliacs receiving pooled clotting factors, and $1.5 \%$ of intravenous drug abusers. None of more than 1000 unselected blood donors were seropositive. $^{6}$

AIDS is a severe disorder of immunoregulation found in previously healthy subjects and occurs most commonly in homosexual males, bisexuals, haemophiliacs, and intravenous drug abusers. ${ }^{7-9}$ Patients may develop opportunistic infections, Kaposi's sarcoma, Pneumocystis carinii pneumonia, and a form of presenile dementia due to HIV related encephalopathy. ${ }^{10}$ The ocular features of AIDS have been reported as including retinal lesions such as cotton wool spots, intraretinal haemorrhages, and toxoplasma and cytomegalovirus (CMV) retinitis, together with conjunctival Kaposi's sarcoma and multiple cranial nerve palsies. ${ }^{11-1+}$ Although these reports do not suggest that cotton wool spots repre-

Correspondence to R C Humphry, FRCS, West of England Eyc Infirmary, Exeter, Devon. sent a prognostic 'marker', severe CMV retinitis occurs in the more severely immunocompromised patients, and an ocular motility disorder suggests an infectious or neoplastic encephalomeningitis. ${ }^{15}$ No prospective study has assessed the temporal associations or prognosis of independent ocular diseasethat is, the ophthalmic features of HIV disease rather than manifestations of AIDS.

Persistent generalised lymphadenopathy (PGL) is an AIDS-related complex (ARC) and is a syndrome found in a similar epidemiological group as for AIDS. It is clinically characterised by lymphadenopathy of more than three months' duration and affecting more than one extrainguinal site in the absence of any other causative illness or drugs. ${ }^{16}$ Other clinical features include malaise, fever, and fatigue. Lymph node biopsy reveals a follicular hyperplasia only. A prospective review of 90 PGL patients, who were not, however, assayed for HIV, suggests that $17 \%$ developed AIDS after 3-13 months. ${ }^{17}$ The ophthalmic features of these patients have not been described to our knowledge.

It was decided to study prospectively a group of patients known to be HIV positive and diagnosed as having either PGL or AIDS to determine their ocular features and to assess their prognostic significance.

\section{Patients and methods}

Twenty-eight male homosexuals were referred for 
ophthalmic review from St Mary's Hospital, London W1, to the Western Ophthalmic Hospital between April 1984 and December 1985. The examining ophthalmologist (RH) was unaware of whether the diagnosis was AIDS or PGL or whether the patient was HIV positive or not. The patients were ambulatory and relatively symptom free at the time of referral. No ocular symptoms or signs had been detected by the referring physicians.

A full ophthalmic history was taken, followed by an ocular examination, including Snellen's visual acuity, slit-lamp observation, and funduscopy after dilating the pupils with tropicamide $1 \%$.

\section{Results}

Twenty-eight patients were assessed over an 18month period. Their ages ranged from 23 to 53 years. Eighteen were diagnosed as having PGL and 10 as AIDS. Sixteen of the PGL and all of the AIDS patients were HIV-positive. They were reassessed at 3-4 month intervals for at least one year. At eight months five failed to attend follow-up, five had died, and one had presenile dementia. At one year 12 failed to attend follow-up and one more had died

Table 1 Failures, deaths, and dementia among 28 patients at four-monthly intervals

\begin{tabular}{lllll}
\hline $\begin{array}{l}\text { Follow-up } \\
\text { period }\end{array}$ & $\begin{array}{l}\text { Total } \\
\text { failures }\end{array}$ & $\begin{array}{l}\text { Total } \\
\text { dead }\end{array}$ & $\begin{array}{l}\text { Total } \\
\text { dementia }\end{array}$ & $\begin{array}{l}\text { Total } \\
\text { remaining }\end{array}$ \\
\hline 4 months & 4 & 3 & 1 & 21 \\
8 months & 5 & 5 & 1 & 17 \\
12 months & 12 & 6 & 1 & 9 \\
\hline
\end{tabular}

(Table 1). Those whose failed to attend follow-up did not acknowledge repeated letters inviting them for assessment and the letters were frequently returned unopened indicating that they had moved address.

The clinical findings are shown in Tables 2 and 3 . Cotton wool spots were found in five of the 10 AIDS patients at some stage of their attendance (Figs. 1a, $b, 2 a, b)$. Two of these patients died within three months of a generalised cytomegalovirus (CMV) infection (cases 1 and 7) without any progression in their fundal features. The cotton wool spots of the remaining three patients had disappeared at the next three-month appointment and the patients remained well. However, at six months two of the patients had died of opportunistic pneumonia (cases 4 and 5) and one had developed HIV related encephalopathy and presenile dementia (case 2).

Cotton wool spots were found in one of the PGL group (case 26, Fig. 3). These were transitory. Six months later, however, the patient developed cotton wool spots again and a Roth spot while suffering from a severe Mycobacterium avium intracellular pneumonia and was diagnosed as having AIDS. The pneumonia did not respond to intensive therapy, and he died eight months after initial referral.

One of the AIDS patients with cotton wool spots developed an internuclear ophthalmoplegia secondary to a presumed brain stem CMV encephalitis at a terminal stage of his illness (case 1). At this stage an intraretinal haemorrhage was also noted (Fig. 1a).

One patient (patient 14) had suffered an attack of ophthalmic herpes zoster, with no permanent sequelae.

Six of the patients complained of tired, itching, or

Table 2 Ophthalmic features and diagnosis in the AIDS group

\begin{tabular}{|c|c|c|c|c|c|c|c|c|}
\hline \multicolumn{4}{|c|}{ Atpresentation } & \multicolumn{5}{|l|}{ During study period } \\
\hline $\begin{array}{l}\text { Patient } \\
\text { number }\end{array}$ & $\begin{array}{l}\text { Systemic } \\
\text { features }\end{array}$ & $\begin{array}{l}\text { Ocular } \\
\text { complaints }\end{array}$ & $\begin{array}{l}\text { Ocular } \\
\text { signs }\end{array}$ & $\begin{array}{l}\text { Ocular } \\
\text { features }\end{array}$ & $\begin{array}{l}\text { Systemic } \\
\text { complications }\end{array}$ & Sequelae & Diagnosis & $\begin{array}{l}\text { HIV } \\
\text { seroassay }\end{array}$ \\
\hline 1 & CMV encephalitis & Diplopia & Bilateral CWS & $\begin{array}{l}\text { Internuclcar } \\
\text { ophthalmoplegia }\end{array}$ & $\begin{array}{l}\text { CMV brainstem } \\
\text { encephalomyclitis }\end{array}$ & Dead & AIDS & $+\mathrm{vc}$ \\
\hline 2 & $\begin{array}{l}\text { Pneumocystis carinii } \\
\text { pncumonia }\end{array}$ & Nonc & $\begin{array}{c}\text { Bilateral CWS } \\
\text { (transient) }\end{array}$ & CWS resolved & $\begin{array}{l}\text { AIDS } \\
\text { encephalopathy }\end{array}$ & Dementia & AIDS & $+v c$ \\
\hline 3 & Kaposi’s sarcoma & None & Nonc & 'Tired cycs' & $\begin{array}{l}\text { Pncumocystis } \\
\text { pncumonia }\end{array}$ & Dead & AIDS & $+\mathrm{vc}$ \\
\hline 4 & $\begin{array}{r}\text { Cryptococcal } \\
\text { pncumonia }\end{array}$ & None & None & $\begin{array}{c}\text { Bilateral CWS } \\
\text { (transicnt) }\end{array}$ & $\begin{array}{c}\text { Cryptococcal } \\
\text { meningitis }\end{array}$ & Dead & AIDS & $+\mathrm{vc}$ \\
\hline 5 & Kaposi's sarcoma & 'Tired cycs' & None & $\begin{array}{c}\text { Bilateral CWS } \\
\text { (transient) }\end{array}$ & Pncumonia & Dead & AIDS & $+\mathrm{vc}$ \\
\hline 6 & Kaposi's sarcoma & Nonc & None & Itchy cycs & None & Alive & AIDS & $+\mathrm{ve}$ \\
\hline 7 & $\begin{array}{l}\text { Toxoplasma cercbral } \\
\text { abscess, candida }\end{array}$ & 'Dry cyes' & Unilateral CWS & Status quo & $\begin{array}{l}\text { Disscminated CMV } \\
\text { and toxoplasmosis }\end{array}$ & Dead & AIDS & $+\mathrm{vc}$ \\
\hline 8 & $\begin{array}{l}\text { Pncumocystis } \\
\text { pncumonia }\end{array}$ & Nonc & Nonc & Nonc & 'Tired' & Alive & AIDS & $+\mathrm{vc}$ \\
\hline 9 & Kaposi's sarcoma & Nonc & None & None & None & Alive & AIDS & $+v c$ \\
\hline 10) & Kaposi's sarcoma & None & None & None & None & Alive & AIDS & $+\mathrm{vc}$ \\
\hline
\end{tabular}

CWS $=$ cotton wool spots. 
Table 3 Ophthalmic features and diagnosis in the PGL group

\begin{tabular}{|c|c|c|c|c|c|c|c|c|}
\hline \multicolumn{4}{|c|}{ Atpresentation } & \multicolumn{5}{|l|}{ During study period } \\
\hline $\begin{array}{l}\text { Patient } \\
\text { number }\end{array}$ & $\begin{array}{l}\text { Systemic } \\
\text { features }\end{array}$ & $\begin{array}{l}\text { Ocular } \\
\text { complaints }\end{array}$ & $\begin{array}{l}\text { Ocular } \\
\text { signs }\end{array}$ & $\begin{array}{l}\text { Ocular } \\
\text { features }\end{array}$ & $\begin{array}{l}\text { Systemic } \\
\text { complications }\end{array}$ & Sequelae & $\begin{array}{l}\text { Initial } \\
\text { diagnosis }\end{array}$ & $\begin{array}{l}\text { HIV } \\
\text { seroassay }\end{array}$ \\
\hline $\left.\begin{array}{l}11,12 \\
13,15 \\
17,20 \\
23,25 \\
27,28\end{array}\right\}$ & None & Nonc & Nonc & Nonc & Nonc & Alive & PGL & All + ve \\
\hline 14 & $\begin{array}{l}\text { Previous herpes } \\
\text { zoster } \\
\text { ophthalmicus }\end{array}$ & Nonc & None & Nonc & Nonc & Alive & PGL & $-v c$ \\
\hline 16 & None & Nonc & None & $\begin{array}{l}\text { Non-bacterial } \\
\text { conjunctivitis }\end{array}$ & Nonc & Alive & PGL & $+v e$ \\
\hline 18 & None & $\begin{array}{l}\text { Aching } \\
\text { cyes' }\end{array}$ & None & None & None & Alive & PGL & $+\mathrm{vc}$ \\
\hline 21 & None & None & None & None & $\begin{array}{r}\text { Streptococcal } \\
\text { pneumonia }\end{array}$ & Alive & PGL & $+v c$ \\
\hline 22 & None & Nonc & None & 'Tired cyes' & Diarrhoca & Alive & PGL & $-v c$ \\
\hline 24 & None & $\begin{array}{l}\text { Recurrent } \\
\text { sty }\end{array}$ & Nonc & Hordcolum & Nonc & Alive & PGL & $+v e$ \\
\hline 26 & None & None & $\begin{array}{l}\text { Unilateral CWS } \\
\text { (transient) }\end{array}$ & $\begin{array}{l}\text { Bilateral CWS and } \\
\text { Roth spots }\end{array}$ & $\begin{array}{l}\text { AIDS Myco. avium } \\
\text { intraccllular } \\
\text { pncumonia }\end{array}$ & Dcad & PGL & $+v e$ \\
\hline
\end{tabular}

aching eyes, while two suffered recurrent styes. There were no conjunctival lesions suggestive of Kaposi's sarcoma, though four of the AIDS patients had Kaposi's sarcoma elsewhere. The eyelids were normal, and there were no features of eczema.

One of the AIDS patients died from Pneumocystis carinii pneumonia without ocular signs (case 3 ). Four of the AIDS and three of the PGL patients complained of non-specific symptoms of aching, itching, or intermittent redness of the eyes. These features were not related to other AIDS complications.

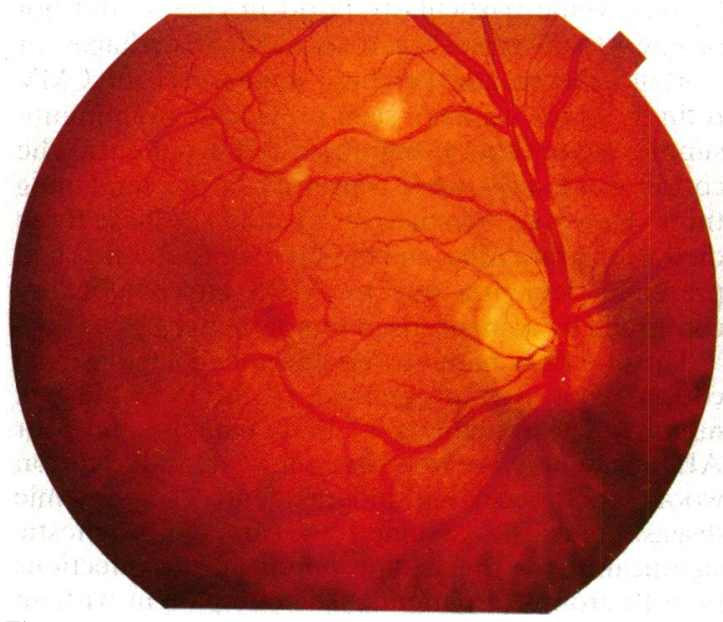

Fig. 1A

\section{Discussion}

In our study the most frequent ophthalmic findings were cotton wool spots. Histological studies show that these are characteristic cytoid bodies. ${ }^{\text {"x }}$ The same paper distinguishes cotton wool spots clinically from CMV lesions by their lack of enlargement and transitory duration during serial observations. Although such cotton wool spots may be unrelated to, or appear before or concurrently with CMV retinitis, their presence suggests a microvascular

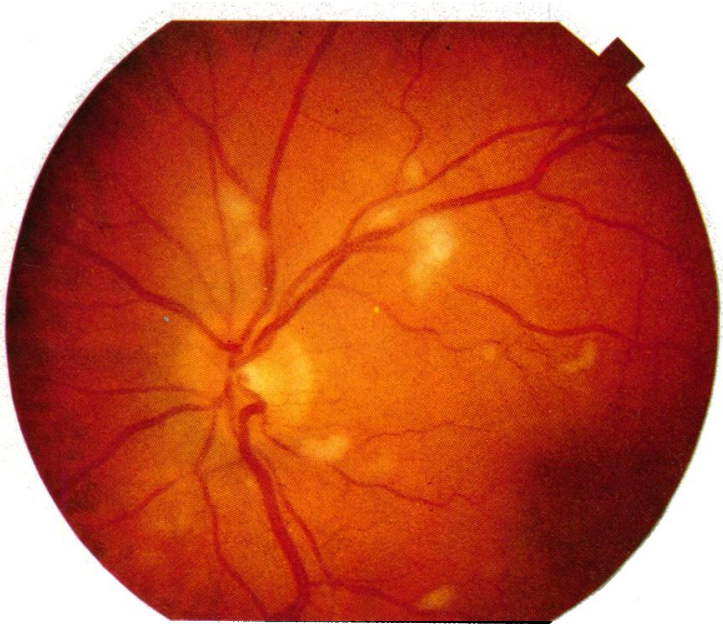

Fig. 1B

Figs. 1A, B Patient 1. Bilateral cotton-wool spots and right intraretinal haemorrhage in an AIDS patient who later died from $C M V$ encephalomyelitis. 


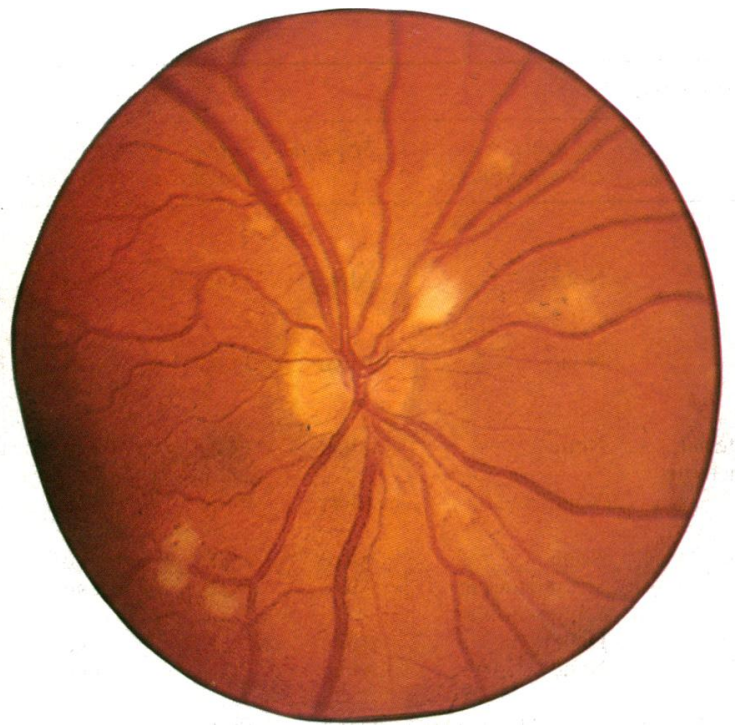

Fig. 2A

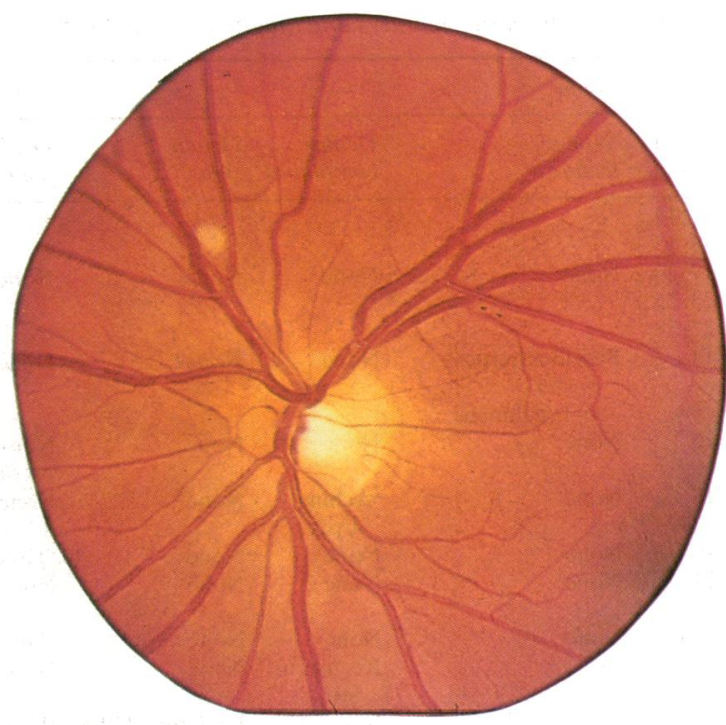

Fig. 2B

Figs. 2A, B Patient 2. Bilateral cotton-wool spots, which resolved three months later, in an AIDS patient who later developed AIDS encephalopathy and dementia.

alteration in AIDS, probably related to the high levels of circulating immune complexes found in the syndrome. ${ }^{12}$ In a later study Pepose et al. ${ }^{11}$ proposed a mechanism linking the deposition of immune complexes to cause microvascular lesions resulting in ischaemia, axoplasmic stasis, and cotton wool spot formation. They further suggest that a CMV viraemia may lead to retinal infection via the

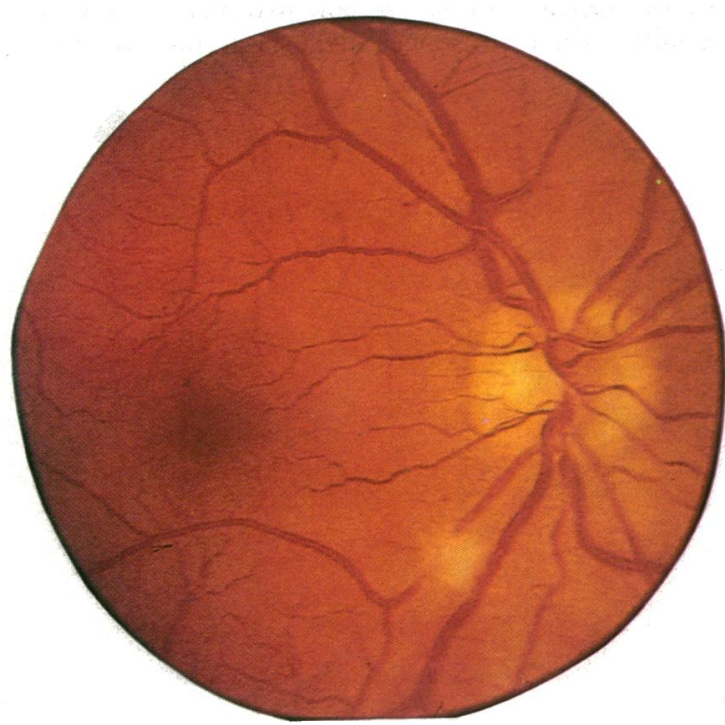

Fig. 3 Solitary cotton-wool spot in the right eye of a patient with PGL who developed AIDS six month later (see text). damaged vascular endothelium. Our five AIDS patients with cotton wool spots did not have coexisting diabetes, hypertension, or collagen vascular disease at the time of their examination. Two of these patients ( 1 and 7 ) died within three months of a generalised CMV infection that was diagnosed clinically and confirmed by laboratory studies.

Despite many studies there have been no reports of virus particles being detected in cotton wool spots. ${ }^{1+1+19}$ These cotton wool spots cannot be considered to represent an early CMV retinitis, since the lesions, while particularly florid in case 1 , did not progress to the typical necrosis and haemorrhages, or 'cottage cheese and ketchup' appearance of CMV retinitis which we have seen previously in immunosuppressed or other hospitalised AIDS patients. The cotton wool spots were transitory in the remaining three. However, two patients (4 and 5) of these three died after six months, and the survivor (patient 2) had presenile dementia due to AIDS encephalopathy confirmed by computerised tomography.

The one PGL patient who developed a (transient) cotton wool spot progressed to AIDS within six months. The remaining 17 PGL patients and four AIDS patients were well after one year, and so cotton wool spots occurring independently of systemic disease must be assumed to carry a prognostic significance for preceeding opportunistic infections in both groups of patients. The one patient with an ocular motility disorder had a CMV encephalitis, confirming reports of the severity of this clinical feature." 
Irritation and itching of the eyes were common in both groups of patients but bore no relationship to the disease state or prognosis. HIV has been isolated from the tears, "I" but there have been no studies to our knowledge of the tear production or profile in such patients.

The involvement of the ophthalmologist with HIV and AIDS related diseases may be varied. An ophthalmologist may be the first to examine an AIDS or pre-AIDS patient with ocular features and may hence assist in the early diagnosis. Indeed this has already occurred at the Western Ophthalmic Hospital. In already diagnosed cases of AIDS or PGL the ophthalmologist may assist in the early detection of ensuing complications, since our results suggest that cotton wool spots act as a 'marker' for patients at risk of early admission to hospital and death. Although, at present, few patients survive more than four months from the onset of CMV retinitis, ${ }^{12} 15$ this is a major form of visual loss in AIDS. As therapy for generalised opportunistic infections improves, it is likely that the ophthalmologist will be asked to assess increasing numbers of visually handicapped patients, since the treatment of CMV retinitis is still undergoing trials. ${ }^{2122}$

We thank Dr A J Pinching and Dr J R W Harris for allowing us to examine their patients, Suc Ford for taking the fundus photographs, and Eleanor Berie for performing the HIV assays; also to Dr D J Jeffries for critically reviewing this manuscript.

We are grateful to the Terrence Higgins Trust for contributing to the cost of the colour illustrations.

\section{References}

1 Gallo RC, Salahuddin SZ, Popovic M, et al. Frequent detection and isolation of cytopathic retrovirus (HTLV III) from patients with AIDS and at risk of AIDS. Science 1984; 224: 5(K).

2 Popovic M. Sarngadharam MG. Read E. Gallo RC. Detection, isolation and continuous production of cytopathic retroviruses (HTLV III) from paticnts with AIDS and pre-AIDS. Science 1984; 224: 497.

3 Schupbach J, Popovic M, Gilden R, Gonda MA, Sarngadharan MG, Gallo RC. Serological analysis of a subgroup of human T lymphotropic retroviruses (HTLV III) associated with AIDS. Science 1984; 224: 503.

4 Sarngadharan MG, Popovic M, Bruch L, Schupbach J, Gallo RC. Antibodies reactive within human T-Iymphotropic retrovirus (HTLV III) in the serum of patients with AIDS. Science 1984; 224: 506.

5 Haverkos HW, Gottlich MS, Killen JY. Edelman R. Classitication of HTLV III/LAV related discases. J Infect Dis 1985; 152: 1095 .

6 Cheingson-Popov R, Weiss RA. Dalgliesh AS, et al. Prevalence of antibody to human T-lymphotropic virus type III in AIDS and AIDS risk patients in Britain. Lancet 1984; ii: 477-80.

7 Gottlicb MS, Schanker HM. Schroff R, et al. Pneumocystis carinii pncumonia and mucosal candidiasis in previously healthy homosexual men: evidence of an acquired cellular immunodeficiency. N Engl J Med 1981; 305: 1425-31

8 Centers for Disease Control. Update on acquired immune deficiency syndrome (AIDS). Morbid Mortal Weekly Rep 1982; 31: 507.

9 Centers for Disease Control. Update on acquired immune deficiency syndrome among patients with hemophilia A. Morbid Mortal Weekly Rep 1982; 31: 644.

10 Centers for Disease Control. Kaposi's sarcoma and pneumocystis pneumonia among homosexual men. Morbid Mortal Weekly Rep 1981; 30: 305 .

11 Holland GN, Gottlicb MS, Yee RD, Schanker HM, Pettit TH. Ocular disorders associated with a new severe acquired cellular immunodeficiency syndrome. Am J Ophthalmol 1982; 93: 393-402.

12 Holland GN, Pepose JS, Pettit TH, Gottleib MS, Yee RD, Foos RY. Acquired immune deficiency syndrome, ocular manifestations. Ophthalmology (Rochester) 1983; 90: 859-73.

13 Rosenberg PR, Uliss AE, Friedland GH, Harris CA. Small CB, Klein RS. Acquired immune deficiency syndrome, ophthalmic manifestations in ambulatory patients. Ophthalmology (Rochester) 1983; 90: 874-8.

14 Schuman JS, Friedman AH. Retinal manifestations of the acquired immune deficiency syndrome (AIDS): cytomegalovirus, Candida albicans, Cryptococcus toxoplasmosis and pneumonocystis carinii. Trans Ophthalmol Soc UK 1983; 103: 177-90.

15 Palestine AG, Rodrigues MM, Macher AM, et al. Ophthalmic involvement in acquired immune deficiency syndrome. Ophthalmology (Rochester) 1984; 91: 1092-9.

16 Centers for Disease Control. Persistent generalized lymphadenopathy among homosexual males. Morbid Mental Weekly Rep 1982: 31: 279-99.

17 Miller B. Stansfield SK, Zack MM, et al. The syndrome of unexplained generalized lymphadenopathy in young men in New York City. JAMA 1984; 251: 242-6.

18 Pepose JS. Nestor MS, Holland GN, Cochrane AJ, Foos RY. An analysis of retinal cotton wool spots and cytomegalovirus retinitis in acquired immune deficiency syndrome. Am J Ophthalmol 1983; 95: $118-20$.

19 Pepose JS, Holland JN, Cochrane AJ, Foos RY. Acquired immune deficiency syndrome. Pathogenic mechanisms of ocular discasc. Ophthalmology (Rochester) 1985; 92: 472-84.

20) Fujikawa LS, Salahuddin SZ, Palestine AG, Masur $H$, Nussenblatt RB, Gallo RC. Isolation of human T-lymphotropic virus type III from the tears of a patient with the acquired immunodeficiency syndrome. Lancet 1985; ii: 529-30.

21 Felsenstein D. D Amico DJ, Hirsh MS, et al. Treatment of cytomegalovirus retinitis with a 9-12-hydroxy-1-(hydroxymethyl) ethoxymethyl| guanine. Ann Intern Med 1985; 103: 377-80.

22 Bach MC. Bagwell SP, Knapp NP, Davis KM, Hedstrom PS. 9-(1,3,dihydroxy-2-propoxymethyl) guanine for cytomegalovirus infections in patients with the acquired immune deficiency syndrome. Ann Intern Med 1985; 103: 381-2.

Accepted for publication 17 July 1986 